\title{
Effects of the Prevailing Zimbabwean Economic Situation on E-Commerce
}

\author{
${ }^{1}$ Gloria Evergrace Mawere \\ Lecturer \\ Department of Accounting and Information Systems \\ Great Zimbabwe University, Zimbabwe
}

\begin{abstract}
This study sought to assess the effects of the prevailing Zimbabwe economic situation on e-commerce. Technology has become the order of the day and many developed countries are using e-commerce technologies to make conducting of businesses and transactions easier and latest developments in technology have not spared Zimbabwe on e-commerce waves. In conducting this research, the researcher used interviews, documentary reviews and focus group discussions as data gathering tools. A randomly selected sample space of fifty respondents was used to acquire data. It was found out that the dwindling Zimbabwean economic situation is hindering the successful full implementation and adoption of e-commerce in Zimbabwe and the government, policymakers and business people were recommended to take into consideration political and economic reforms to enjoy economic growth for it was concluded that e-commerce is dependent on the economy.
\end{abstract}

Keywords: Economy; E-Commerce; Prevailing and Economic Situation.

\section{INTRODUCTION}

E-commerce refers to the trading of goods or services over computer networks such as the internet (Batani, Denhere and Mawere, 2015). E-commerce is a process that describes the buying, selling, transferring, or exchanging products, services or information through computer networks, mainly the Internet (Turban, King, Lee and Viehland, 2004).With the emergence of new technologies, e-commerce has become a large part of some businesses' structure, complementing traditional commercial buying and selling activities. Many researches have been carried out on the benefits of and barriers to e-commerce adoption as well as evaluating availability and usage of information technology enabling e-commerce. Mupemhi et al (2011) indicated that e-commerce has offered quite a number of business opportunities as well as improving business performance but there are hindrances to using e-commerce enabling technologies like high costs, legislation, fear of technological change, lack of sufficient supporting infrastructure and shortage of appropriate skills. According to Zanamwe et al (2012), some of the barriers to using technology enabling ecommerce include lack of resources, knowledge, skills, level of employees, security concerns, cost and complexity. In Zimbabwe e-commerce was becoming a common subject of discussion and great strides were being made towards adoption and usage of ecommerce with increasing internet penetration but still the growth rate of e-commerce is still very low. Despite all the

\author{
${ }^{2}$ Trust Mutero \\ Lecturer \\ Department of Accounting and Information Systems \\ Great Zimbabwe University, Zimbabwe
}

positivity e-commerce adoption can bring to organizations and to the country as a whole, and efforts to address most barriers to adoption especially the issue of security of online payments, Zimbabwe seems to still be at its infant stage and it is slowly progressing as far as e-commerce is concerned.

\section{RESEARCH OBJECTIVE}

The major objective of this paper is to highlight the effects of the prevailing Zimbabwean economic situation on successful e-commerce implementation and adoption.

\section{BENEFITS OF E-COMMERCE}

The growth of the internet as a viable business vehicle for conducting business transactions is one of the phenomena of modern information technology and has already had a significant impact on the business community, providing new methods of conducting business on a global basis (Jutla, Bodorik, Hajnal \& Davis 1999). According to Nyoni (2018), the country's export promotion body, ZimTrade, has been pushing for adoption of e-commerce revealing that the growing availability and use of the internet in global business was an opportunity that all micro, small, and medium-sized enterprises (MSMEs) in Zimbabwe should investigate as they look to take a share of the e-commerce market. The ZimTrade report stated that by taking their businesses online, MSMEs could access international markets to find new customers and build value through exposure to new trends and technologies. ZimTrade encouraged Zimbabwean companies to invest in the development of online stores to interface with and sell to customers from around the globe for convenient shopping for customers as they can instantly make orders and pay for goods and services using secure online payment methods such as PayPal, or the local equivalent, PayNow (Nyoni 2018). In an endeavour to capacitate local companies with online skills, ZimTrade has been conducting trainings on marketing and branding for international competitiveness (MBIC), including a module on online and social media marketing. This course helps equip Zimbabwean exporters with skills on how to make use of e-commerce to increase their exports. 


\section{PREVAILING ZIMBABWEAN ECONOMIC SITUATION}

The economy of Zimbabwe has been dwindling hence the need for the researcher to investigate the prevailing economic environment may hinder the successful full implementation and adoption of e-commerce in Zimbabwe. Economy refers to the state of a country or region in terms of the production and consumption of goods and services and supply of the money (Batani et al, 2015). Zimbabwe owes money to multilateral lenders such as the International Monetary Fund (IMF), World Bank, African Development Bank (ADB), and the European Investment Bank. According to Zimbabwe's Minister of Finance and Economic Development, Hon. Patrick Chinamasa, the country is also indebted to every country in Europe and also to China, Japan, India, South Korea, and Kuwait among other bilateral creditors (Munzara 2015). The source of the debt crisis in Zimbabwe is threefold (Munzara 2015). Firstly, at independence the country inherited a debt of US\$700million from the former colonial government. Secondly, in the years following independence the government had to borrow heavily as it sought funding to correct colonial imbalances by improving access to social services such as health and education by the majority of the people. Mostly, the loans were used to finance recurrent expenditures such as paying government workerse salaries or to pay existing debts instead of being invested in capital projects. As a result the loans did not generate returns to fund repayment of the loans. A significant portion of foreign loans were also channelled to setting up state enterprises but these turned out to be loss making entities and an embarrassing drain on the fiscus. Thirdly, poor policies by the government also compounded the debt crisis. For example, the country involved itself in an unsanctioned and expensive war in the Democratic Republic of Congo (DRC) in the late 1990s (Munzara, 2015). Currently the country is saddled with $\$ 1,7$ billion of arrears owed to the African development Bank and World Bank that it needs to repay before it can tap new loans from multilateral lenders. According to The World Bank Development report (2018) Zimbabwe faces challenges relating to fiscal consolidation and financial sector stabilization; stimulating growth and investment to increase revenue collection and foreign exchange generation; protecting social gains; and improving governance outcomes through continued legislative and institutional reforms. In 2015, after a period of recovery (2010 to 2014), Zimbabwe's economy began a downward trend, that saw a decline in gross domestic product (GDP) growth due to a drought and fall in commodity prices; an expansionary fiscal policy that led to a burgeoning fiscal deficit; rising vulnerability and poverty because of weather and financial shocks; and acute foreign currency shortages dampening demand and supply.

\section{METHODOLOGY}

The researcher interviewed a number of people on their views on the effects of the Zimbabwean
Economy on e-commerce usage and transactions. The researcher interviewed a sample of fifty, drawn from across the country, ten economic experts, five academics, and five Information Technology experts as well as thirty purposively selected individuals and business owners who engage in online transactions. The sample of respondents was carefully selected from those groups assumed to have knowledge of e-commerce and the economy. An organised set of questions was used for the interviews. The researcher also reviewed journals, textbooks, conference proceedings, newspaper articles, websites, and blogs in gathering data for the purposes of this research. Focus group discussions with some of the interview respondents were used to compliment and validate interviews and documentary reviews findings. Focus groups can unearth a wealth of detailed information and deep insight (Eliot 2005).

\section{DISCUSSION OF FINDINGS}

Almost most of the respondents agreed that the prevailing Zimbabwean economic situation was derailing the progress that had been made on the efforts to attain higher levels of adoption and usage of e-commerce. Many cited that most online transactions they were doing as part of e-commerce were with international trading partners and they are no longer doing them because the government allocates foreign currency only to those who generate foreign currency and companies that import raw materials as it insists that the bond note quasi-currency in circulation in Zimbabwe is equal in value to the dollar, despite a parallel market valuation premium of up to 250percent. Respondents also said the other factor that is hindering the growth in ecommerce is the suspension of online payments by most banks due to the currency instability hence the impact of the prevailing economic situation on e-commerce. Prevailing cash shortages were supposed to be countered by ecommerce transactions with people resorting to online trading but the suspension of online payments dampened everything.

Internet access is another issue that is affecting e-commerce usage. Many agreed that fertile ground for e-commerce strategy and adoption had been provided by the presence of the various social media platforms such as Facebook, Instagram and Pinterest, which have huge user bases and international reach. This is supported by the ZimTrade report which argued that whether conducting direct sales, or marketing an online store, if done well, social media should play a central role in how Zimbabwean companies grow their exports hence supporting e-commerce. However for users who do not have access to broadband e-commerce is not always an effective alternative to traditional shopping and in the Zimbabwean current scenario most families incomes have been eroded by inflation and the internet service providers are also charging exorbitant prices in a bid to avoid losses in the harsh economic environment hence making many not able to afford to pay a daily/weekly/monthly subscription for internet access, meaning they cannot benefit from the lower prices of ecommerce. Internet service provision interruptions are also being frequently interrupted because the providers have also 
challenges in procuring infrastructure rendered by the bad economic situation therefore due to internet access challenges in Zimbabwe, some respondents argue that it would be difficult for e-commerce to thrive as it requires people to buy and sell online.

The issue of multicurrency and payment methods is another challenge in doing online payments in an unstable economy like Zimbabwe. Global ecommerce means accepting a variety of payment methods and currencies. Electronic payments such as e-wallets, mobile payments, and credit/debit cards help online merchants compete in international markets by allowing their customers to pay in their native currencies. For merchants, multi-currency, cross-border transactions can require new bank accounts, new business entities, and new regulatory hurdles in each national market and the turbulent economic situation is not helping the situation.

The respondents also argued that corruption issues, lack of rule of law and ill- conceived economic policies affect the execution of online transactions for trading partners lack confidence in the authenticity and security of online transactions which is a critical success factor for ecommerce. Customer and card data security is top priority and preventing online payment security issues is a must for anyone doing business online. The disputed 2018 election and legitimacy issues also contribute to the economic chaos hence impacting on e-commerce with international trading partners.

\section{CONCLUSIONS}

In summary, the present study highlights the necessity of taking into consideration the economic situation in pushing for the adoption of e-commerce for findings showed that ecommerce is heavily dependent on the economy. Based on the study made and discussion presented above, the following broad conclusions are drawn:

$>$ Policymakers and business leaders must work hand in hand to enable improved conditions of the internet ecosystem maybe by also allocating foreign currency to the internet service providers.

$>$ Discussions revealed that the election was about the economy not politics hence the need for economy rehabilitation creating a conducive environment for e-commerce hence resuscitating economic growth.

$>$ Government of Zimbabwe together with other responsible organizations should work towards combating the endemic corruption which has so much devastated the economy and the nation for the efforts to revive the economy and save the country from the current economic quagmire in which the nation currently is to materialise. This seconds Batani et al (2015) recommendations on role of e-commerce in resuscitating the economy.

$>$ The country should avoid ill-conceived economic policies for example the controversial legislation enacted in 2010 that requires foreign businesses operating in the country to cede at least $51 \%$ of the shareholding to black Zimbabweans shareholding to black Zimbabweans and rebrand itself and come out of the international economic isolation so that it can attract foreign direct investment (FDI). The country has been accused of lack of the rule of law hence some potential foreign investors have been deterred as a result. This impacts negatively on ecommerce.

\section{REFERENCES}

1. Amos Tendai Munzara(2015), Impact of Foreign Debt on Economic Growth in Zimbabwe ; IOSR Journal of Economics and Finance (IOSR-JEF) e-ISSN: 2321-5933, p-ISSN: 23215925.Volume 6, Issue 5. Ver. II (Sep. - Oct. 2015),

2. Batani J, Denhere P.T and Mawere T (2015), The Role of ecommerce in Resuscitating the Economy of Zimbabwe PDF) The Role of e-commerce in Resuscitating the Economy of Zimbabwe. Available from: https://www.researchgate.net/publication/280529713 The Role of e-commerce in Resuscitating the Economy of Zimbabwe [accessed Jan 04 2019].

3. Eliot, Associates (2005),"Guidelines for Conducting a Focus Group", Retrieved December 01, 2018, from Trinity College of Arts \& Sciences: https://assessment.aas.duke.edu/documents/ How_to_Conduct_a_Focus_Group.pdf.

4. Jutla, D., Bodorik, P., Hajnal, C., \& Davis, C. (1999b). Making Business Sense of Electronic Commerce, COMPUTER 32(3), March 1999, IEEE CS Press, 67-75

5. Mupemhi S, Mupemhi R, and Duve R, E-commerce in Agro-food industry: Myth or reality, IJMBS, 1(4), 2011

6. Nyoni M, (2018); ZimTrade pushes for adoption of e-commerce; https://www.thestandard.co.zw/2018/07/22/zimtrade-pushesadoption-e-commerce/

7. The World Bank Development Report, (2018) https://www.worldbank.org/en/country/zimbabwe/overview

8. Turban, E., King, D., Lee, J., Viehland, D.,"Electronic commerce: A Managerial perspective", New Jersey: Pearson/Prentice Hall, 2004.

9. Zanamwe N, Bere M, Zungura C, Nyamakura S.A, and Muchangani B, E-commerce usage in pharmaceutical sector of Zimbabwe, Journal of Internet Banking and Commerce, 17(1), 2012 